\title{
Physical Education Classroom Management and Social Inclusion
}

\author{
Eva Julianti*, Mulyana Mulyana \\ Physical Education Department \\ Universitas Negeri Jakarta \\ Jakarta, Indonesia \\ *eyulianti@unj.ac.id,mulyana@unj.ac.id
}

\author{
Heni Widyaningsih \\ Sport Science Department \\ Universitas Negeri Jakarta \\ Jakarta, Indonesia \\ hwidyaningsih@unj.ac.id
}

\begin{abstract}
The aims of this study is to find out how the management of physical education learning classes in inclusive schools affects the social inclusion of students including students with special needs. And the results are expected to provide solutions to the problem of social inclusion in inclusive schools. Because researchers have not found many references to the real characteristics of social inclusion patterns in physical education learning then what findings / innovations targeted in this study are social inclusion patterns of students and students with special educational needs and/or disabilities (SEND) formed as a result of classroom management in physical education learning. Respondents are PE teachers. Use the case study method with a qualitative approach to answer research questions. Two semistructured interviews were conducted with the teacher and two observations were carried out in the same class. An interpretation approach based on hermeneutical is used for the analysis of the results obtained. Data for physical education learning activities for 3 weeks were collected using video recordings, direct observations, and interviews. The data reveal that classroom management has not yet promoted social inclusion, because teacher knowledge in inclusive education is less clear and is based more on subjective impressions and assessments. The term social inclusion seems to be an unfamiliar concept, although in practice the teacher is in accordance with the ideas of social inclusion. In addition, teachers in their application to help interaction between students use the same approach for all students and do not specifically organize activities to influence the participation and interaction of SEND students. Further, the data shows the relationship between teacher knowledge and practice. Teacher enthusiasm and creativity are also components that greatly affect the observed application. Overall, the observed data reflect the data spoken
\end{abstract}

Keywords: inclusive education, social inclusion, physical education, classroom management

\section{INTRODUCTION}

Social inclusion for most people may be something sensitive to discuss, but something that must be discussed, as a form of our sensitivity to the conditions around. At school, this is the teacher's job as a facilitator between students, helping student interactions, to be more positive and cooperative. As mentioned by Kirk, Macdonald and O'Sullivan that teachers have the power to provide opportunities for frequent, meaningful, pleasant, long-lasting, and equal status interactions for SEND and regular students who encourage the achievement of affective learning outcomes for all students [1]. Social inclusion is an attempt to replace the general practice in society, namely social exclusion, which is defined as 'the process through which individuals or groups are fully or partially excluded from full participation in the society in which they live [2].

UNESCO stated, although education can contribute to promoting equality of opportunity among people to include it in society, a minimum level of social justice is also needed to achieve democratization in access to knowledge. This will enable everyone to obtain the competencies needed to participate in various fields of social life. Inclusive schools promote the process of addressing and responding to the diverse needs of all students through increasing participation in learning, culture and society, and reducing exclusion in and from education [3]. Inclusive schools do not have any selection or discrimination mechanism. Instead, he changed his pedagogical proposal into a way of integrating student diversity, thereby encouraging social cohesion, which is one of the main goals of education [4-6].

\section{THEORETICAL FRAMEWORK}

Physical education according to Nichols is an aspect of education in schools that is designed to develop skills, fitness and movement knowledge through a series of motor activities planned and carried out carefully [7]. Harold M. Barrow and Rose Mary Me Gee in Tritschler have different definitions of physical education, namely: an education of and through human movement where many of the educational objectives are achieved by means of big muscle activities involving sports, games, gymnastic, dance and exercise [8].

Physical education is one of the compulsory subjects in schools including junior high school, because physical education is included in the education curriculum. In the Permendiknas No 22 it is stated "Physical education is part of the educational process through providing learning experiences to students in the form of physical, play, and sports activities that have been systematically planned to stimulate physical growth and development, motor skills, thinking skills, emotional, social, and moral" [9].

Class management is important as a bridge between the expectations of the curriculum and the reality in the classroom. 
guide children to new skills, new thinking and opportunities for interaction. The role of the teacher in classroom management is thought to bring success in students' social inclusion.

The World Bank provides a definition of social inclusion, namely: 1.The process of increasing the requirements for individuals and groups to take part in society, 2.The process of increasing the abilities, opportunities, and dignity of those who are less fortunate based on their identities to take part in society. Included in disadvantaged individuals or communities are those who live below the poverty line, as well as individuals who have physical and mental limitations.

Inclusive education implies the involvement of students with all kinds of special needs in the educative process together with peers. It also includes teaching with individual and/or modified educational plans (inclusive education in Javakhishvili [12]). Furthermore, Deborah Stienstra believes that disability is not about the 'wrong' body that needs to be fixed, but about the reaction of the organization, culture and attitudes towards differences and physical shortcomings, and that the neoliberal notion of independence and individualism is at the core of ongoing discrimination against 'disabled' [13]. Furthermore, the meaning of 'disabled' and SEND in this study, citing Stienstra disability is as experiences from attitudinal and environmental (structural) barriers that result in exclusion from participation because of bodily differences or body forms [13]. Social inclusion is a movement of awareness to eliminate social exclusion. According to OHCHR, persons with disabilities should be able to live independently and participate fully in all aspects of life. Therefore all related parties must ensure that persons with disabilities have access to 1) physical accessibility; 2) service accessibility; 3) accessibility to communication and information. Other mentions, inclusive education is accepting children with special needs and learning and participating in activities in school and in the classroom like other children.

Indonesia is trying to implement this, including access to education. So that inclusive schools are then applied and now all schools must be inclusive schools. Inclusive schools are educational services provided for SEND in obtaining proper education, as stipulated in Law Number 20 of 2003 in article 32 and Permendiknas No. 70/2009, namely by providing opportunities and opportunities for children with special needs to obtain education at regular schools.

Inclusive schools allow SEND students to learn together with normal children, and are treated like normal children. This shows the positive impact of inclusive schools on children with special needs from a psychological perspective. However, in its implementation various problems arise, according to Pratiwi are [14]:

- Teachers' feelings of lack of competence;

- Limited facilities and infrastructure;

- The need for collaboration;

- Administrative burden and curriculum modification; and role. Furthermore, Social Constructivist Theory and Structural Cognitive Modification Theory emphasizes the responsibility of the teacher as a mediator and as a competent person who can
According to Bronfenbrenner in Maia in Javakhishvili, placing teachers in the system closest to the child (micro system) [12]. Interpersonal relationships that occur there are the main builders of the system. Therefore, the placement of teachers in the micro system reinforces the importance of their 
Furthermore, about how physical education teachers in

- Low awareness of parents and the community towards children with special needs.

Göransson \& Nilholm proposed four definitions of inclusive education [15]:

- Paying attention to the placement of special needs students;

- Paying attention to meeting their social / academic needs;

- Meet the social and academic needs of all students; and

- Inclusive education as creating community, which is based on the notion of "fairness, care, respect for knowledge and respect for diversity.

\section{METHOD}

This research is a qualitative descriptive study, which tries to explain the phenomena that exist in inclusive classes in physical education lessons. The method used is interviews and inclusive classroom observation in physical education lessons using video recordings.

The key to successful social inclusion is classroom management and promotion to foster social inclusion by teachers. To measure classroom management, an instrument based on the question of research on how the teacher manages the classroom manages the scope of the rules and discipline. While for the promotion of social inclusion based on research questions namely how the teacher's understanding of social inclusion whose scope is:

- How do teachers understand the concepts of inclusion in general and certain social inclusions?

- How do teachers practice social inclusion and inclusion?

- How do teachers promote interaction between regular students and students with special needs?

\section{FINDINGS}

\section{A. Description}

Descriptions of respondents in this study were male teachers aged 55 and 40 years, with a college education background, a physical education study program, teaching experience between 14-27 years, and this was the first semester to receive inclusion students.

We asked the physical education teacher some open questions and gave the questionnaire closed questions, in addition to answering in writing also conducted interviews with the teacher. For questions about understanding inclusive education, teachers respond almost the same, that inclusive education is accepting children with special needs and learning and participating in activities in school and in the classroom like other children. The teacher also did not know and understand about social inclusion, the response given: "I do not understand social inclusion, maybe the social relations of SEND students and other students". secondary schools practice learning inclusion and social inclusion, it was found that: "I do not have special activities for special needs students, lessons run as usual, special needs students may choose to do what they can, listen and may also sit just waiting for lessons to finish "and" I don't understand social inclusion ". In preparation if a physical education teacher must teach in an inclusive class, what will be done is "I am trying to help SEND students to be able to follow the subject matter, and ask other students to help". But the teacher does not know what will be done to improve students' social inclusion. sentence, what will be done to help social interaction between students in inclusive classes, the teacher answers: "I will encourage and command the same assignments, and ask other students to pay attention to the needs of special needs students and immediately help them and provide equal opportunities for all students and invite all to do joint activities."

Answering the question what will be done in teaching physical education material, the teacher answers: we have two SEND students, low vision / blind and a bit mentally retarded, we cannot do the same thing as other children, but let them try, and if not willing to join, we allow the student to sit alone during the Physical Education lesson. Example; join in the warm-up, assisted by his friend, walk around the field, and a little movement. To make an assessment of learning outcomes, the teacher experienced obstacles, so what was done was: "yes this is a rather difficult part for us, I made an assessment of the results of the written test, and for the value of the skills to take a minimum grade / Minimum Learning Completeness (KBM)". The teacher also has not yet determined alternative activities for SEND students: "We are also still confused about what to give, only giving the opportunity to participate in a little warmup movement before starting the subject matter".

Respondents also filled out questionnaires about inclusion and class management. The average score obtained by the teacher shows that $71 \%$ has fulfilled the principle of promoting social inclusion. For classroom management, the teacher has done well. This shows that teachers who manage class well, also make efforts to promote social inclusion. This is reflected in the teacher's agreement on statements related to support for social inclusion.

Based on observations made during the teacher and students are in learning, when teaching basketball games, the teacher includes all students, both regular and $\mathrm{ABK}$ students in starting the learning, giving an explanation of the material to be taught. Then warm up together. Several times the teacher asks students to help ABK students who have low vision about the movements that must be done. When students begin to use the ball to learn passing, ABK students are given the ball to be felt and asked to throw in the suggested direction, while other regular students pass in pairs. After doing a few basketball passes with the help, ABK students are allowed to sit and other regular students continue with other activities. At the end of the lesson, the teacher reminds the regular students to help ABK students return to class, and some others press and return equipment. If the question about social inclusion is clarified by the 
develop new strategies that can help all students to develop and get the best learning results

\section{REFERENCES} school teachers and pre-service teachers have better attitudes; teaching experience and teacher education level does not affect the teacher's attitude; and 3) teachers who have a good attitude towards inclusive education are teachers who have a good understanding of inclusive education policies, have participated in inclusive education training, have positive experiences in learning in inclusive classes and have high self-efficacy to practice in inclusive classes. Based on observations, the teacher actually has promoted social inclusion, although in the statement, the teacher does not know what is meant by social inclusion. This is in line with Maria opinion that the differences between what teachers think they know about inclusive education, what they really know and what they actually do in this area should pull out an alarm signal for the decision factors that can make a reform in order to increase teachers' level of competence for inclusive practices [17].

\section{CONCLUSION AND IMPLICATION}

Implementation of the results of this study is to develop better patterns of social inclusion and the benefits of student character formation. This research was conducted in several Secondary Inclusion Schools and measured the social inclusion of special needs students and other students. This study illustrates the behaviour of special educational needs and/or disabilities (SEND) and regular students are relative to social inclusion in physical education subjects in public schools.

Based on the research findings formulate further implications for teachers. First, because knowledge in inclusive education and social inclusion seems low and second, because there is a relationship between knowledge and application, it is recommended to increase teacher awareness about inclusion. In addition, it is also recommended to support enthusiasm and creativity as a determinant of teacher practice. The findings in this study are expected to find out how regular students interact socially with SEND students.

The quality of education depends on the quality of teachers who carry out classroom management activities: organizing, implementing and evaluating teaching activities. Receiving and understanding alone is not enough for inclusive education. It is very important to apply the principles of inclusive teaching,
[1] D. Kirk, D. Macdonald, and M. O’Sullivan, Handbook of Physical Education, London: SAGE Publication, 2006.

[2] N. Rawal, "Social Inclusion and Exclusion: A Review," Dhaulagiri Journal of Sociology and Anthropology, vol. 2, pp. 161-180, 2008.

[3] UNESCO, Guidelines for inclusion: ensuring access to education for all, 2005 .

[4] UNESCO, Understanding and Responding to Children's Needs in Inclusive Classrooms, 2001

[5] UNESCO, Overcoming exclusion through Inclusive Approaches in education, 2003.

[6] UNESCO, Defining an Inclusive Education Agenda: Reflections around the 48th session of the International Conference on Education. Geneva, 2008.

[7] B. Nichols, Moving and Learning: The Elementary School Physical Education Experience (3rd ed.), NY: McGraw-Hill College, 2001.

[8] K. Tritschler, Barrow and McGee's Practical Measurement and Assessment, Baltimore: Lippincott Williams \& Wilkins, 2000.

[9] Depdiknas, Permendiknas No. 22 tentang Tujuan Pendidikan Jasmani Olahraga dan Kesehatan, 2006.

[10] J.R. Chepyator-Thomson and W. Liu, 'Pre-service teachers' reflections on student teaching experiences: Lessons learned and suggestions for reform in PETE programs," Physical Educator, vol. 60(2), pp. 2-12, 2003.

[11] D. Cothran and P. Kulinna. "Classroom Management in Physical Education," Journal of Physical Education, Recreation \& Dance, vol. 57(6), pp. 29-32, 2015.

[12] M. Javakhishvili, How are teachers promoting social inclusion ? A study of teachers' contribution to social, 2012.

[13] D. Stienstra, About Canada: Disability Rights, Fernwood Publishing Co., Ltd., 2012.

[14] J.C. Pratiwi, "Sekolah Inklusi Untuk Anak Berkebutuhan Khusus: Tanggapan Terhadap Tantangan Kedepannya," Prosiding Seminar Nasional Pendidikan "Meretas Sukses Publikasi Ilmiah Bidang Pendidikan Jurnal Bereputasi,” pp. 237-242. 2013.

[15] K. Göransson and C. Nilholm, "Conceptual diversities and empirical shortcomings - a critical analysis of research on inclusive education," European Journal of Special Needs Education, vol. 29(3), pp. 265-280, 2014.

[16] S. Kielblock, Inclusive Education for All: Development of an Instrument to Measure the Teachers 'Attitudes, 2018, Retrieved from http://hdl.handle.net/1959.14/1265466.

[17] U.E. Maria, "Teachers' Perception, Knowledge and Behaviour in Inclusive Education," Procedia - Social and Behavioral Sciences, vol. 84, pp. 1237-1241, 2013. 